\title{
Preliminary Study on Spawning Period and Length at Maturity of Short- fin Scad, Decapterus macrosoma, (Bleeker, 1851, Perciformes:Carangidae) from the Coastal Waters of San Fernando, Romblon
}

\author{
Betcieva G. Rada ${ }^{\star 1}$, Emelia B. $\operatorname{Ramos}^{1}$, Carmen J. Riva ${ }^{1}$,Noel R. Royo ${ }^{1}$ \\ ${ }^{1}$ Teacher Education Department, Romblon State University-San Fernando Campus, San Fernando, Romblon, 5513 \\ Philippines
}

\begin{abstract}
A B S T R A C T
A preliminary study on spawning period, length at maturity, and main fishing grounds of Decapterus macrosoma (shortfin scad) collected from coastal waters of San Fernando, Romblon, Philippines were conducted. A total of 1,168 specimens were collected from July 2016 to December 2017. From these specimens, the minimum and maximum total lengths were $11.50 \mathrm{~cm}$ to $22 \mathrm{~cm}$ while its body weights ranged from $13 \mathrm{~g}$ to $100 \mathrm{~g}$, respectively. D.macrosoma was capable of spawning whole year round. Two spawning peaks were observed (February and August to October) based on the monthly mean gonadosomatic indices. Male appeared to dominate female, as evidenced by its sex ratios. The lengths at $50 \%$ maturity of female and male D. macrosoma were estimated at $15.29 \mathrm{~cm}$ and $17.22 \mathrm{~cm}$, respectively. D. macrosoma was caught in volume through commercial ring net at a depth of about $150 \mathrm{~m}-200 \mathrm{~m}$ within the municipal waters. Coastal waters near barangay Canjalon and Agtiwa were identified as the main fishing grounds of D. macrosoma in San Fernando, Romblon. This initial data on spawning period may be used as a basis in implementing closed fishing season of D. macrosoma in the locality, and the length of maturity may as well be used for the allowable size of the capture of this species.
\end{abstract}

E-mail address: queendrethmhaey17@yahoo.com*

Received: January 24, 2019

Accepted: April 29, 2019
Keywords: Spawning period, length at maturity, fishing ground, Decapterus macrosoma

\section{I N T R O D U C T I O N}

$\mathrm{F}$ isheries are culturally, economically, socially, and ecologically important to Filipinos. They contribute significantly to income, employment, foreign exchange earnings, and nutrition. Fish is the world's fifth largest agricultural resource which accounts for $7.5 \%$ of total world food production (Green et al. 2003). Fish has always been a common table commodity for most Filipinos. It is a vital source of food and the single most important source of high-quality protein and polyunsaturated fatty acids (Sangalang and Quinay 2015).

Decapterus macrosoma (shortfin scad) is one of the six known species in the Philippines which are locally known as "galunggong" belonging to the family of Carangidae. Decapterus spp. commonly known as round scads are considered as the most important small pelagic fish species due to its availability throughout the year from municipal and commercial catches all over the country (Calvelo 1992), and also as one of the most essential pelagic fishes caught in large quantities in the Philippine waters most of the year (Pastoral et al. 2000).

People of San Fernando, Romblon depend greatly on fishing and farming as their major occupations and sources of income (DA-BFAR 2011). However, Philippine fishery resources are rapidly depleted as evidenced by the decline of fish catch in the country (Green et al. 2003). Overfishing and over-dependence on the marine resources for food and income have long been considered pressing issues that significantly affect fisheries resources. Fish as a critical source of food such as round scads, sardines, and anchovies is 


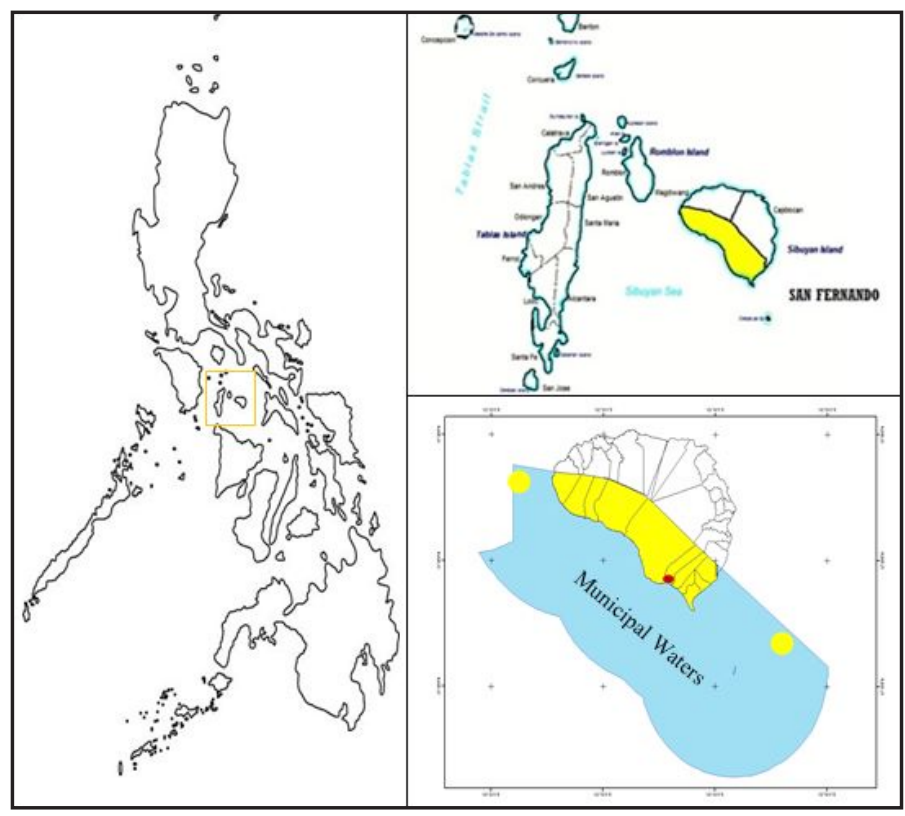

Legend:

ion of the public market of San Fernando where the specimen are bought

- location of the two main fishing ground of D. macrosoma within the municipal waters of San Fernando, Romblon

Figure 1.Map of Sibuyan Island showing the location of the public market and the two main fishing grounds.

increasingly becoming scarcer (Ani 2016). Likewise, Bersales and Bautista (2018) stated that there is a decrease in volume production of round scad in the last five years. From 270.80 metric tons in 2013 down to 183.10 metric tons in 2017, while its average retail price continued to increase from $\mathrm{P} 108.02$ per kilogram in 2013 to $\mathrm{P} 127.50$ per kilogram in 2018. This is also true in the area where data shows that there is a considerable decrease in the average fish catch per day from 1990 to 2010. This scenario puts fishing as a source of income at risk. Likewise, if fish catch continues to decrease, its price would continue to rise, which makes it unaffordable for ordinary people (DA-BFAR 2011). Republic Act No. 10654 entitled "An Act to Prevent, Deter, and Eliminate Illegal Unreported and Unregulated Fishing" amending Republic Act No. 8550 otherwise known as "The Philippine Fisheries Code of 1998" provides the legal framework and guiding principles for the utilization, management, protection, and conservation of the coastal and fisheries resources. It also aims for rational and sustainable development of coastal and fishery resources in the light of the concept and principle of integrated coastal area management, which requires a holistic approach to solving environmental problems, not only by managing the coastal waters, but also taking care of the adjacent coastal areas (Gonzales and Bhagwani 2005).

In response to the aforementioned act, Northern Palawan which is near the province already established a closed season for the management of "galunggong" (round scad; Decapterus spp.) in 2015 through the Department of Agriculture (DA) and the Department of Interior and Local Government (DILG) Joint Administrative Order (JAO) No. 1. The JAO was initiated to achieve sustainability and climate change resiliency of the round scad fishery in Palawan, however the municipality of San Fernando, Romblon was not covered in the fishing ban or closure period. Since then, there was no policy formulated in the locality to ban fishing for a specific period.

Furthermore, many studies were already conducted on the age and growth of D. macrosoma. However, very few of them were conducted about the spawning period and length of maturity of this species. Likewise, no researches were conducted yet on the said species in San Fernando, Romblon, Philippines.

Thus, this study aims to determine the spawning period, length of maturity, and locate the main fishing ground of D. macrosoma in San Fernando, Romblon. Through this research, baseline information about the reproductive biology of $D$. macrosoma is shown which can be used as a basis in formulating policy on sustainable fish management in the locality.

\section{MATERIALS AND METHODS}

\subsection{Study area}

This study was conducted at San Fernando, Romblon ( $12^{\circ} 34^{\prime} 34^{\prime \prime}$ North, $122^{\circ} 16^{\prime} 16^{\prime \prime}$ East) 
(Fig. 1). It is the biggest municipality in Sibuyan Island, Romblon. It has a total land area of $201.90 \mathrm{~km}^{2}$ (Fadri 2003). San Fernando is a coastal town categorized as a 4th class municipality where fishing and farming are the major sources of income of its people.

\subsection{Data Gathering}

A minimum of 50 pieces (July, August, and September 2016) and a maximum of 145 pieces (January 2017) specimens were collected from July 2016 to December 2017. Samples were bought from the public market of San Fernando, Romblon since there are no specified landing centers established yet in the municipality during the conduct of the study. For the first three (3) months of this study, samples were collected once a month, but from the succeeding months, samples were collected twice a month.

No specimens were collected during October, November, and December 2016 due to typhoons (Lawin, Marce, and Nina). Likewise, no specimens were collected during November and December 2017 due to inclement weather and typhoons (Ramil, Salome, Tino, Urduja, and Vinta).

Specimens were brought to the laboratory for measurements and further processing. Total length (TL), fork length (FL), and standard length (SL) were determined in centimeters $(0.1 \mathrm{~cm})$ while weight was measured in grams $(1 \mathrm{~g})$. Sex determination was done through individual gonad. Female gonads appeared yellowish to orange while male gonads appeared whitish. Gonads were removed, blotted dried, and weighed. These were used to compute the GSI of individual fish.

\subsection{Data Analysis}

Spawningperiodwascomputedusinggonadosomaticindex (GSI) (Borthakor 2018) with the formula:

$$
\mathrm{GSI}=(\mathrm{GW} /(\mathrm{BW}-\mathrm{GW}) \times 100
$$

where GSI is gonadosomatic index, GW is gonadweight, andBWistotalbodyweightwithintactgonad.

The individual GSI were averaged monthly to determine the peak of spawning. This was presented in a line graph.

The length at maturity for male and female were identified following the macroscopic descriptions of the various reproductive phases by Peterson et al. (2011) as shown in Table 1.

The length of maturity was calculated using the percentage of mature specimens from the total samples. A logistic function was fitted to the frequency of mature fish for each body size class with $1 \mathrm{~cm}$ interval using least squares regression to estimate the total length (TL) at 50\% maturity (L50). The formula from Karna and Panda (2011) was used.

$$
M(T L)=\frac{1}{\left[1+e^{(a T L+b)}\right]}
$$

where $\mathbf{M}(\mathbf{T L})$ is the mean length at maturity in TL, $\mathbf{a}$ and $\mathbf{b}$ are constants.

Fishing grounds for D. macrosoma was determined from interviews and focus group discussion with the fishermen and fish vendors in the locality.

Table 1.Macroscopic descriptions of the female and male fish reproductive

\begin{tabular}{|c|c|c|}
\hline \multirow{2}{*}{$\begin{array}{c}\text { Reproductive } \\
\text { phase }\end{array}$} & \multicolumn{2}{|c|}{ Macroscopic descriptions } \\
\hline & Female & Male \\
\hline I. Immature & $\begin{array}{l}\text { Small ovaries, often } \\
\text { clear, blood vessels } \\
\text { indistinct }\end{array}$ & $\begin{array}{l}\text { Small testes, often } \\
\text { clear and thread- } \\
\text { like. }\end{array}$ \\
\hline II. Developing & $\begin{array}{l}\text { Enlarging ovaries, } \\
\text { blood vessels } \\
\text { becoming more } \\
\text { distinct }\end{array}$ & $\begin{array}{l}\text { Small testes but } \\
\text { easily identified. }\end{array}$ \\
\hline $\begin{array}{l}\text { III. Spawning } \\
\text { Capable }\end{array}$ & $\begin{array}{l}\text { Large ovaries, } \\
\text { blood vessels } \\
\text { prominent. } \\
\text { Individual oocytes } \\
\text { visible macroscop- } \\
\text { ically }\end{array}$ & $\begin{array}{l}\text { Large and firm } \\
\text { testes. Actively } \\
\text { spawning subphase } \\
\text { (macroscopic): milt } \\
\text { released with gentle } \\
\text { pressure on the } \\
\text { abdomen }\end{array}$ \\
\hline IV. Regressing & $\begin{array}{l}\text { Flaccid ovaries, } \\
\text { blood vessels } \\
\text { prominent }\end{array}$ & $\begin{array}{l}\text { Small and flaccid } \\
\text { testes, no milt re- } \\
\text { lease with pressure. }\end{array}$ \\
\hline V. Regenerating & $\begin{array}{l}\text { Small ovaries, } \\
\text { blood vessels re- } \\
\text { duced but present }\end{array}$ & $\begin{array}{l}\text { Small testes, often } \\
\text { threadlike. }\end{array}$ \\
\hline
\end{tabular}
phases

\section{RES ULT S}

\subsection{Size composition}

There were 1,168 specimens collected from the coastal waters of San Fernando, Romblon from July 2016 to December 2017. The length of D. macrosoma ranges from $11.50 \mathrm{~cm}$ to $22 \mathrm{~cm}$ with a mean of 16.52 $\mathrm{cm}( \pm 0.46)$. The minimum and maximum mean total lengths were $14.05 \mathrm{~cm}$ and $18.73 \mathrm{~cm}$, respectively. In 

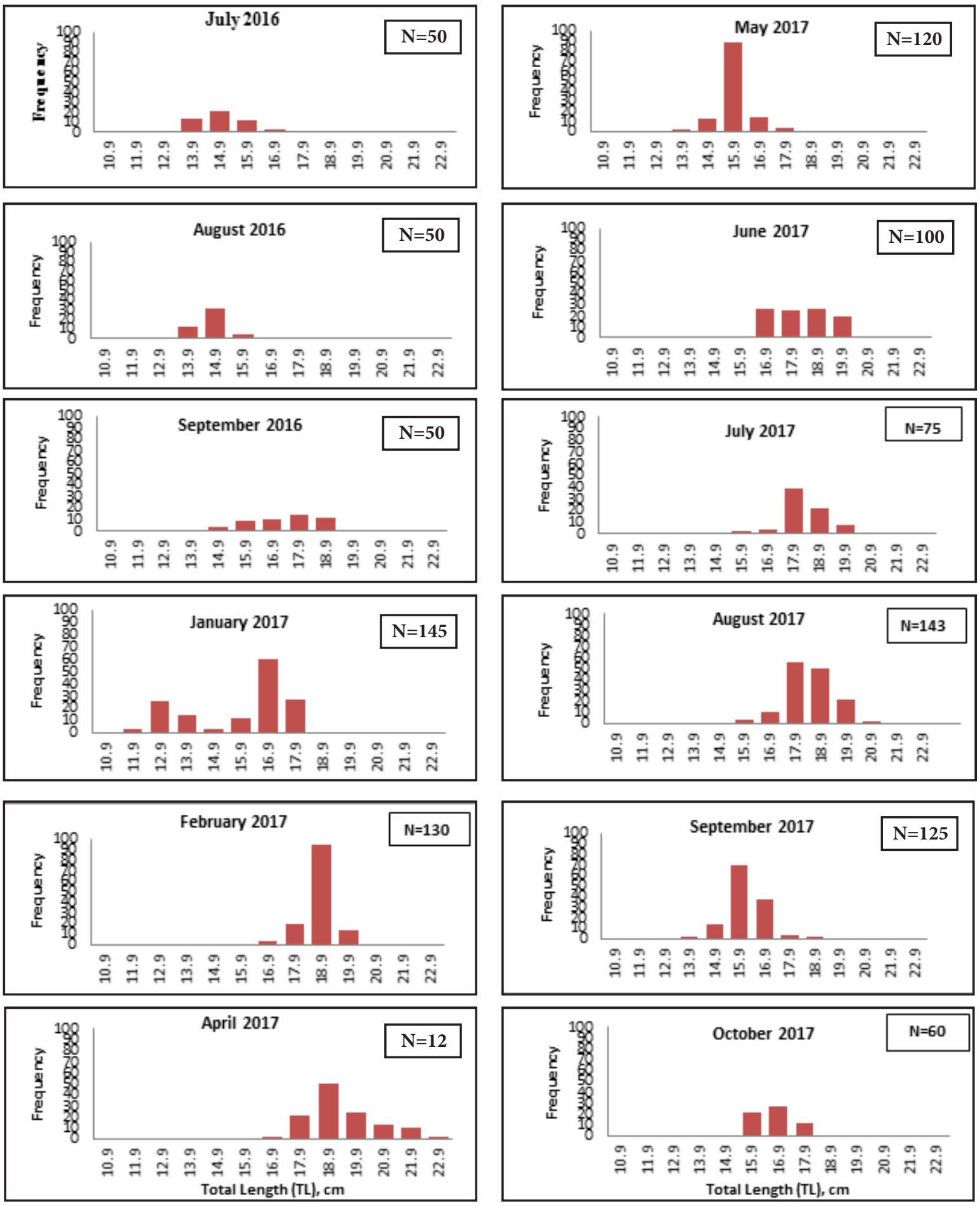

Figure 2. Length-frequency distribution of Decapterus macrosoma in San Fernando, Romblon from July 2016 to December 2017 (N=1,168). No specimens were collected during October, November, and December 2016 due to inclement weather conditions and typhoons Lawin, Marce, and Nina, as well as in November and December 2017 due to typhoons Ramil, Salome, Tino, Urduja, and Vinta. 
terms of its body weight, the range was 13 g-100 $\mathrm{g}$ with a mean of 43.94 g. Also, it is evident that there's a more dispersed distribution of samples during January and April with a ranging from $6 \mathrm{~cm}$ $(11.50 \mathrm{~cm}-17.50 \mathrm{~cm})$ to $5.60 \mathrm{~cm}(16.40 \mathrm{~cm}-22$ $\mathrm{cm}$ ) compared to the distribution of samples in July, August, September, and February (Fig. 2).

\subsection{Sex Ratio}

Sex ratios were determined using specimens collected from July 2016 to August 2017. From 1,168 specimen collected, there were 476 male or $53.54 \%$, 413 or $46.46 \%$ female, and 279 or $23.89 \%$ undetermined sex (Table 2). Based on the data, there were more males compared to females D. macrosoma collected during the conduct of the study. Greater differences in sex ratios were observed in July and August 2017, and April, September, and June 2017. Minimal sex ratio differences were observed from June to August 2017, and from January to February 2017. In contrary, there were greater sex ratio differences in September and October 2017. Equal sex ratio was noticed in May 2017. The mean sex ratio value computed was 1:0.87, which means that in every male there are 0.87 female.

\subsection{Spawning Period}

The spawning period was identified based on the GSI and macroscopic stages of gonadal development. It was observed that matured gonads for both sexes were present in D.macrosoma during the sampling months. A total of 889 (476 males and $413 \mathrm{fe}$ males) were considered in computing for the Gonado2017
Table 2. Ratio of male to female D. macrosoma in Coastal waters of San Fernando, Romblon from July 2016 to December

\begin{tabular}{|c|c|c|c|c|c|}
\hline Months & Male $(\mathrm{m})$ & Female (f) & Undetermined & Sex Ratios & $\mathrm{X} 2$ \\
\hline July 2016 & 2 & 1 & 47 & $1: 0.50$ & 0.17 \\
\hline Aug. 2016 & 11 & 6 & 33 & 1: 0.54 & 0.74 \\
\hline Sept. 2016 & 29 & 19 & 2 & 1: 0.66 & 1.04 \\
\hline Oct. $2016^{*}$ & - & - & - & - & - \\
\hline Nov. $2016^{\star}$ & - & - & - & - & - \\
\hline Dec. $2016^{*}$ & - & - & - & - & - \\
\hline Jan. 2017 & 55 & 45 & 45 & 1: 0.82 & 0.5 \\
\hline Feb. 2017 & 70 & 60 & 0 & 1: 0.86 & 0.39 \\
\hline Mar. 2017** & - & - & - & - & - \\
\hline Apr. 2017 & 75 & 44 & 1 & 1: 0.59 & 0.39 \\
\hline May 2017 & 6 & 6 & 108 & $1: 1.00$ & 4.04 \\
\hline Jun. 2017 & 60 & 40 & 0 & $1: 0.67$ & 2.00 \\
\hline July 2017 & 38 & 32 & 5 & 1: 0.84 & 0.26 \\
\hline August 2017 & 82 & 61 & 0 & 1: 0.74 & 1.54 \\
\hline September 2017 & 34 & 55 & 36 & $1: 1.62$ & 2.48 \\
\hline October 2017 & 14 & 44 & 2 & $1: 3.38$ & 8.43 \\
\hline November $2017^{\star}$ & - & - & - & - & \\
\hline December $2017^{\star}$ & - & - & - & - & \\
\hline Total & 476 & 413 & 279 & 1: 0.87 & 2.23 \\
\hline
\end{tabular}

somatic index (GSI). Undetermined samples were not included. The monthly mean GSI for male ranged from $0.61-2.58$ with a mean of $1.33( \pm 0.18)$, and the female mean GSI ranged from $0.86-3.83$ with a mean of 2.09 $( \pm 0.27)$. The highest female mean GSI was observed in February with a mean of 3.83 , followed by September with 3.54, August with 3.27, and October with 2.02 . Furthermore, the highest male mean GSI was also in February, August, and September, respectively. Therefore, it can be assumed that the peak of their spawning period was during these months (Fig. 3 and Fig.4).

3.4 Sexual maturity

The estimated length at sexual maturity of fe- 


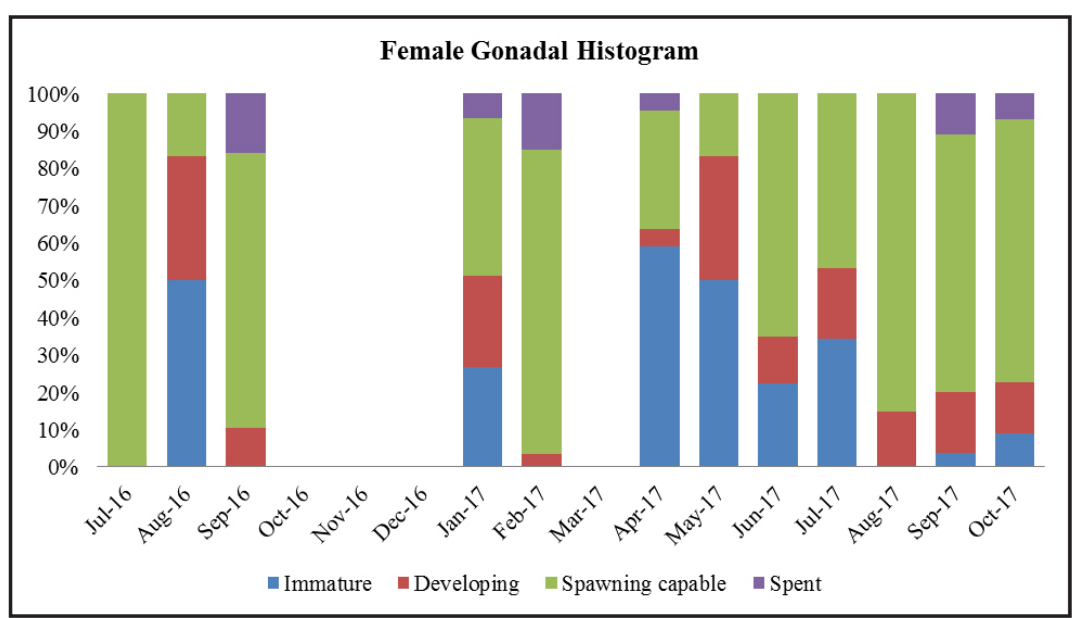

Figure 3. Female D. macrosoma monthly gonadal histogram

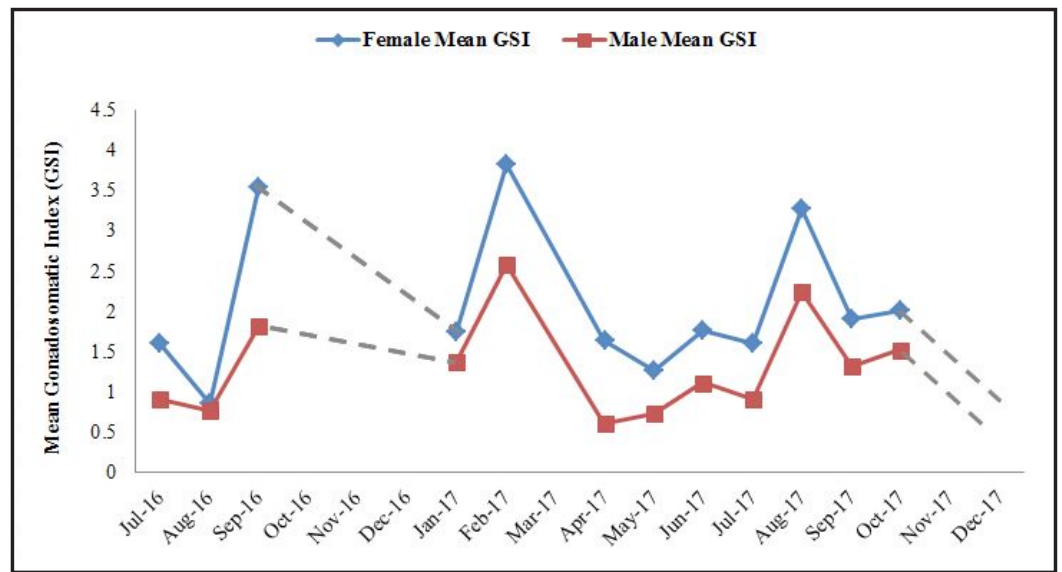

Figure 4. Monthly Mean GSI for both male and female D. macrosoma
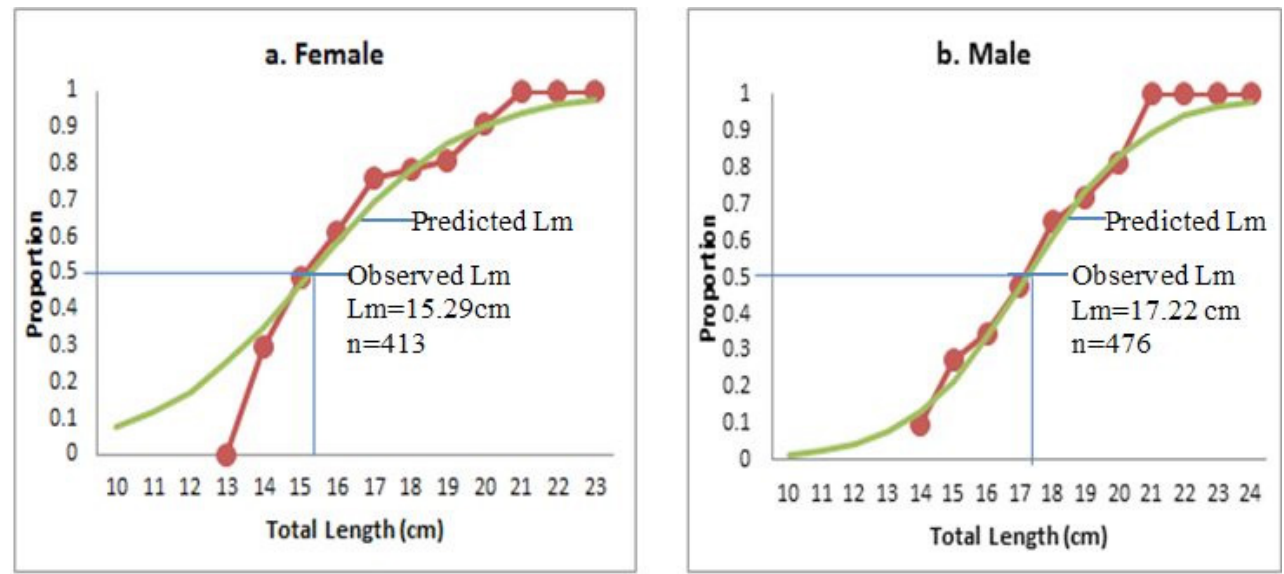

Figure 5. Estimated length at 50\% maturity of (a) female and (b) male D. macrosoma in the coastal waters of San, Fernando, Romblon 
male $D$. macrosoma was $15.29 \mathrm{~cm}$ while male $D$. macrosoma was $17.22 \mathrm{~cm}$. Thus, for female D. macrosoma at $15.29 \mathrm{~cm}$ and above of total length, most of the fish are identified as reproductive (mature and capable of spawning). Likewise for male D. macrosoma, at 17.22 $\mathrm{cm}$ and above of total length, most of the fish are identified as reproductive (mature and capable of spawning). It was also observed that female D. macrosoma matures earlier than its male counterpart (Fig. 5).

\subsection{Fishing Grounds}

Interviews with the local fishermen, fish vendors, and fishing vessel operator in the municipality revealed that there were two main fishing grounds for D. macrosoma which are the coastal areas near barangay Canjalon and Agtiwa which are still part of the municipal waters (Fig.1). D. macrosoma were mainly caught in volume through commercial fishing operations using ring net at a depth of about $150 \mathrm{~m}-200$ $\mathrm{m}$. The volume of catch ranged from $250 \mathrm{~kg}$ to 750 $\mathrm{kg}$ per fishing operation. It was confirmed that there were no commercial fishing activities from November to December due to inclement weather conditions and also to give time for the fish to reproduce.

\section{D I S C U S S I O N}

The minimum and maximum total length of $D$. macrosoma observed in this study ranges from 11.50 $\mathrm{cm}$ to $22 \mathrm{~cm}$. This result is closer to the values reported by Widodo (1988, cited in Pattikawa et al. 2017) with a total length ranging from 13.50 to $25.30 \mathrm{~cm}$. However, this range is narrower compared to other studies. Pattikawa et al. (2017) reported a total length ranging from 13.30 to $31.50 \mathrm{~cm}$ in eastern waters of Ambon Island, Indonesia. Senen et al. (2011) stated that the total length of this species ranges from 7.50 to $31.50 \mathrm{~cm}$ in Banda Neira waters, Maluku Province while Suwarni et al. (2015) reported a range of 12.10 to $29.50 \mathrm{~cm}$ in Bone Bay waters, South Sulawesi. Also, Rohit and Shanbhogue (2005) recorded a maximum length of 232 $\mathrm{mm}$ or $23.2 \mathrm{~cm}$. of D. macrosoma in Karnataka Coast, India. It is observed in this study that the total lengths of the specimen collected were limited only in a shorter range, which resulted in a constricted histogram. This may be due to the gear type used, which is only limited to ring net and mesh size selectivity. Besides, the samples were bought only in one specific area, which is the public market, and not in the landing centers. Thus, further studies may be conducted using exhaustive sampling and considering different fishing gears.
Results of this study based on the GSI shows that the peaks of the spawning periods of D. macroso$m a$ are in February, August, and October. This result supports the findings of Sousa and Gjøsaeter (1987) that there were two spawning seasons of $D$. macrosoma in Mozambique that is from December to February and June to September. Likewise, it was also reported by Balasubramanian and Natajaran (2000) in India that D. macrosoma breed continuously with two spawning peaks, which were from February, June, October, and December. Furthermore, Shiraishi et al. (2010) also affirmed that the peak of spawning of this species was from February to April while Senen et al. (2011) affirmed that the fish spawned between February and March. However, GSI alone cannot solely support the spawning period. Other parameters should still be considered to help support the findings. In this study, the lengths of maturity of female and male D. macrosoma are $15.29 \mathrm{~cm}$ and 17.22 $\mathrm{cm}$, respectively. The values obtained were closer to the data from Palawan wherein the length at maturity of D. macrosoma in 2013-2014 was $16.39 \mathrm{~cm}, 17.85$ $\mathrm{cm}$ in 2015-2016, and $19.39 \mathrm{~cm}$ in 2016-2017 (DADILG 2015). Likewise, Widodo (1991) reported that the length at maturity of D. macrosoma in the Java Sea is $155 \mathrm{~mm}(15.50 \mathrm{~cm})$ for female and $148 \mathrm{~mm}(14.80$ $\mathrm{cm}$ ) for male. Similarly, the values obtained by Balasubramanian and Natajaran (2000) in India, stated that female and male D. macrosoma attained maturity at $157 \mathrm{~mm}(15.70 \mathrm{~cm})$ and $158 \mathrm{~mm}(15.80 \mathrm{~cm})$, respectively. However, the values obtained from this study are shorter compared with the length of maturity of D. macrosoma affirmed by Shiraishi et al. (2010) with a value of $232 \mathrm{~mm}$ or $23.20 \mathrm{~cm}$. It can also be noted that the difference in the values obtained about length at maturity of $D$. macrosoma can be attributed to environmental factors, habitat, and biological characteristics. Previous studies on Decapterus spp. indicate that growth and reproductive characteristics differ among different habitats (McBride et al. 2002; Ohshimo et al. 2006). Some studies have indicated the influence of environmental factors on biological characteristics. Brander (1994) and Campana et al. (1995) confirmed that growth of fishes in areas of high water temperature (low latitude regions) is faster, and the size at sexual maturity is smaller than that of areas with low water temperature (high latitude regions). The influence of this factor seems to be true since the Philippines is located in the tropical region with warmer average seawater temperature, thus influencing the sexual maturity of $D$. macrosoma at shorter lengths compared to high latitude regions. 
In San Fernando, Romblon, D. macrosoma was commonly caught in volume using commercial ring net within the municipal waters. There were two identified areas which served as the main fishing grounds for D. macrosoma. These are the coastal areas near barangay Canjalon and Agtiwa. They usually caught this species at about $150 \mathrm{~m}-200 \mathrm{~m}$ deep. The volume of catch ranged from $250 \mathrm{~kg}$ to $750 \mathrm{~kg}$ per fishing operation. Moreover, the supply of fish was only marketed within the municipality and the surplus to nearby towns and islands.

\section{C O N C L US I O N}

This research provides preliminary information on the spawning period, length at maturity, and main fishing grounds of shortfin scad (Decapterus macrosoma) in the coastal waters of San Fernando, Romblon. There were 1,168 specimens of $D$. macrosoma collected during the study period with the total lengths ranging from 11.50 to $22 \mathrm{~cm}$ and weights ranging from 13 to $100 \mathrm{~g}$. The initial result revealed two spawning peaks (February and August to October). Moreover, the lengths at maturity for female and male D. macrosoma were estimated at 15.29 $\mathrm{cm}$ and $17.22 \mathrm{~cm}$, respectively. D. macrosoma was caught in volume through commercial fishing using ring net at a depth of about $150 \mathrm{~m}-200 \mathrm{~m}$. Coastal waters near barangay Canjalon and Agtiwa were identified as the main fishing grounds of $D$. macrosoma in San Fernando, Romblon. Further studies are needed to help supplement and substantiate the data.

\section{A C K N O W L E D G M EN T}

We are very grateful to Dr. Benjamin J. Gonzales and Dr. Herminie P. Palla of Western Philippines University for the motivation and untiring support they have extended in mentoring and guiding us in this study. Also to Dr. Arnulfo F. de Luna, the University President; Dr. Arthur R. Ylagan, Vice President for Research and Extension; and to Dr. Borromeo B. Motin, the Director for Research-University system for the support and trust they have given us for this endeavor. The researchers are also thankful to their research assistants for the encoding and processing of data, and to Ronaldo A. Amorin for making the map needed in this study. We are also indebted to the fishermen, fish vendors, and commercial fishing vessel operator who willingly helped and gave significant information relevant to this research. Lastly, we would like to express gratitude to the two anonymous reviewers who offered suggestions and comments to substantiate this paper further.

\section{REFERENCES}

Ani PA. 2016. Enriching the Philippine fisheries resources through closed fishing season policies. Fisheries Articles.

Balasubramanian NK, Natajaran P. 2000. Studies on the Biology of Scads, Decapterus russelli and Decapterus macrosoma at Vizhinjam, Southwest Coast of India. Indian J. Fish, 291-300.

Bersales LG, Bautista R. 2018. Selected Statistics on Agriculture 2018. Philippine Statistics Authority [PSA]. Available at http://psa. gov.ph/sites/default/files/Selected\%20Statistics\%20on\%20Agriculture\%202018.pdf

Borthakur MKr. 2018. Study of gonadosomatic index and fecundity of freshwater fish Xenontedon cancila. Journal of Entomology and Zoology Studies. 6(3): 42-46.

Brander KM. 1994. Patterns of distribution, spawning, and growth in North Atlantic cod: the utility of inter-regional comparisons. ICES Mar. Sci. Symp. 198: 406-413.

Calvelo RR. 1992. Synopsis of biological and related data on Philippine roundscads. Philippine Journal of Fisheries, 51-80.

Campana SE, Mohn RK, Smith SJ, Chouinard GA. 1995. Spatial implications of a temperature-based growth model for Atlantic cod (Gadus morhua) off the eastern coast of Canada. Can. J. Fish. Aquat. Sci. 52:2445-2456.

[DA-BFAR] Department of Agriculture and Bureau of Fisheries and Aquatic Resources Region IV-B. 2011. Municipal Coastal Environment Profile San Fernando, Romblon. p. 40

[DA-DILG] Department of Agriculture and Department of Interior and Local Government. 2015. Implementation and Effectiveness of DA-DILG JAO No.1 Series of 2015. Establishment of a Closed Season for the Management of Galunggong (Roundscads; Decapterus spp.) in Northern Palawan. 
Fadri LF. [Internet]. 2003. Profile of the Province. Sanrokan.com; [updated 2003 Oct 2; cited 2018 Nov 15]. Available from http://sanrokan.com/ newsanrokan/archives/romblon_profile.htm.

Gonzales BJ, Bhagwani ET. 2005. Healing of nature by ICRM. In faces of the sea. 2nd Edition. Quezon City, Philippines: Fisheries Resource Management Project, Bureau of Fisheries and Aquatic Resources. Department of Agriculture.

Green SJ, White AT, Flores JO, Carreon III MF, Sia AE. 2003. Philippine fisheries in crisis: A framework management. Cebu City: Cebu City, Philippines.

Karna SK, Panda S. 2011. Growth estimation and length at maturity of a commercially important fish species i. e., Dayscieaena albida (Boroga) in Chilika Lagoon, India. European Journal of Experimental Biology 1(2):84-91.

McBride RS, Stengard FJ, Mahmoudi B. 2002. Maturation and diel reproductive periodicity of round scad (Carangidae: Decapterus punctatus). Marine Biology 140: 713-722.

Ohshimo S, Yoda M, Itasaka N, Morinaga N, Ichimaru T. 2006. Age, growth and reproductive characteristics of round scad Decapterus maruadsi in the waters off west Kyushu, the East China Sea. Fisheries Science 72:855-859.

Pastoral PC, Severino Jr. EL, Lamarca, NJ. 2000. Round scad exploration by purse seine in the South China Sea, Area III: Western Philippines. Proceedings of the SEAFDEC Seminar on Fishery Resources in the South China Sea, Area III: Western Philippines.

Pattikawa JA, Tetelepta JMS, Ongers OTS, Ureputty PA, Lewerissa H. 2017. Size, distribution, length-weight relationship and age group of $\mathrm{De}$ capterus macrosoma in eastern waters of Ambon Island, Indonesia.AACL Bioflux.10(4):969-976.
Peterson NJB, Wyanski DM, Rey FS, Macewicz BJ, Barbieri SKL. 2011. A standardized terminology for describing reproductive development in fishes. Marine and Coastal Fisheries:Dynamics, Management, and Ecosystem Science 3: 52-70.

Rohit P, Shanbhogue SL. 2005. Age and growth of Decapterus russelli and D. macrosoma along Karnataka Coast, India. Journal of Marine Biological Association of India, 47(2): 180-184.

Sangalang RH, Quinay EB. 2015. Lead content of Rouns Scad (Decapterus macrosoma) from Batangas Bay, Philippines. Asia Pacific Journal of Multidisciplinary Research 3(4): 118-124.

Senen B, Sulistiono, Muchsin dI. 2011. Aspek biologi ilan Layang Deles (Decapterus macrosoma) di perairan Band Neira,Maluku. Jurnal Pertanian-UMMI 1(1): 34-40.

Shiraishi T, Tanaka H, Ohshimo S, Ishida H, Morinaga N. 2010. Age, growth and reproduction of two species of Sscad, Decapterus macrosoma and D. macarellus in the Waters off Southern Kyushu. JARQ 44 (2):197-206.

Sousa MI, Gjøsaeter J. 1987. Reproduction, age, and growth of Round Scad (Decapterus macrosoma) Blecker 1851, Caragidae from Mozambique. Revista de Investigacao Pesqueira Maputo 16:1-17.

Suwarni, Tresnati J, Umar MT, Nur M, Hikmasari. 2015. Estimation of population dynamics parameters of mackerel fish (Decapterus macrosoma, Bleeker 1841) in the waters of Bone Strait, South Sulawesi. Torani (Jurnal Ilmu Kelautan dan Perikanan) 25 (1):53-60.

Widodo J. 1991. Maturity and spawning of shortfin scad (Decapterus macrosoma) (Carangidae) of the Java Sea. Asian Fisheries Science 4:245-252. 